\title{
Britain and the World: A New Field?
}

\section{Tehila Sasson, James Vernon, Miles Ogborn, Priya Satia, Catherine Hall}

\begin{abstract}
Over the past decade, historians, journals, conferences, and even job advertisements have devoted attention to a new field of inquiry, "Britain and the world." This emergent category is far from coherent but, despite a variety of approaches, shares a common assumption that Britain's interactions with the world beyond its shores enable us to better understand the histories of both Britain and the globe. Writing the history of Britain from a comparative, imperial, or transnational perspective is not wholly new. British historians have long worked comparatively in a predominantly European frame, while historians of empire and internationalism have also highlighted the importance of transnational and global frameworks. What, then, is signified by the articulation of "Britain and the world" as a new field? What do historians of Britain, and indeed historians of its empire and the world, stand to gain or lose from the promotion of Britain and the world as a field? What new skills, methodologies, and archives are required to become a historian of Britain and the world? We invited historians from different generations and national academies as well as with different ways of approaching the history of Britain in an extranational frame. Our hope is that these essays will open up debate and stimulate broader discussions about the changing nature of the field and our work as historians of Britain.
\end{abstract}

\section{INTRODUCTION}

\section{Tehila Sasson and James Vernon}

n or around the year 2008, a new field called "Britain and the world" materialized. It was in 2008 that Miles Ogborn published Global Lives: Britain and the World, 1550-1800 and the journal Britain and the World was launched. Soon after, universities began to advertise positions for historians of "Britain and the world." In 2010, Macquarie University in Australia appointed a historian of the "British world." In North America, the Universities of Rochester and Richmond both advertised positions in "Britain and the world" in 2014, and Emory University

Tehila Sasson is an assistant professor in the Department of History at Emory University; James Vernon is a professor in the Department of History at University of California, Berkeley; Miles Ogborn is a professor in the School of Geography, Queen Mary University of London; Priya Satia is a professor in the Department of History at Stanford University; and Catherine Hall is a professor in the Department of History at the University College London. This forum began as a roundtable at the North American Conference on British Studies conference in Washington, DC, in November 2016, shortly after the United Kingdom European Union membership referendum (23 June 2016) and in the immediate aftermath of the 2016 US presidential election. We thank Philippa Levine and Susan Pennybacker for participation in the roundtable and the audience members for their contributions, and the four anonymous reviewers for Journal of British Studies. Please direct any correspondence to tsasson@emory.edu. 
followed suit in 2015. By 2017 the Universities of York and Birmingham in Britain had also hired historians in this field. ${ }^{1}$

At first glance, we might assume that the new category was a product of the Great Recession of 2007 and the decade of budgetary crises that followed in higher education across much of the world. At least in North America and Australia, where positions in British history have shrunk, "Britain and the world" was born out of material needs as much as from an intellectual agenda. And yet, when universities across the former British world start employing historians of Britain and the world, the phrase also begins to take a life and meaning of its own that transcend the institutional specificities of each locale. That so many scholars have conjured up this somewhat peculiar framework raises questions of what the category actually means, what possibilities it offers for writing history in different ways, the methods and research strategies it demands, and the ways they might be used to reconfigure the field of British history.

To be sure, writing the history of Britain from a comparative, imperial, or transnational perspective is not particularly new. British historians have long worked comparatively in a predominantly European context, while historians of the Atlantic world, the empire, and international relations have also highlighted the importance of transnational and global frameworks. ${ }^{2}$ Even before the recent global turn, colonial and so-called "third world" intellectuals sought to decolonize and provincialize histories produced in the Euro-American academy, while from the 1960s some Marxist historians, occasionally drawing on world systems theory, endeavored to show the connections between Britain and various regions of the globe. ${ }^{3}$ During the 1980s, imperial historians called for greater understanding of how British power both worked and took shape in disparate colonial territories across the globe. "It is an anachronism," to recall C. A. Bayly, "to think of Indonesia, India, the Caribbean, let alone 'Europe' or 'Asia,' as separate or separable entities." $\mathrm{By}$ the 1990s, feminist and postcolonial historians like Antoinette Burton were calling upon imperial studies to relinquish national imaginaries and stop conserving the boundaries of the British state. ${ }^{5}$

Furthermore, British historians were hardly the first to "world" their field. Historians of France, Germany, and the United States have increasingly situated their work in broader transnational or global perspectives. ${ }^{6}$ The turn toward provincializing

\footnotetext{
${ }^{1}$ For example, Tehila Sasson was hired as a historian of Britain and the world in 2017 at Emory University, and James Vernon has worked with those appointed at Macquarie University, Emory University, and University of York.

${ }^{2}$ It is impossible to survey here the entire literature that sought to resituate British history in broader geographical frames. In the essay below, James Vernon tries to cover some of this ground.

${ }^{3}$ Canonical examples include C. L. R. James, Black Jacobins: Toussaint Louverture and the San Domingo Revolution (London, 1938); Eric Williams, Capitalism and Slavery (Chapel Hill, 1944); Eric Hobsbawn, Industry and Empire: An Economic History of Britain since 1750 (London, 1963); Immanuel Wallerstein, The Modern World System, 3 vols. (New York, 1974-1989); Giovanni Arrighi, The Long Twentieth Century: Money, Power, and the Origins of Our Times (London, 1994).

${ }^{4}$ C. A. Bayly, Imperial Meridian: The British Empire and the World, 1780-1830, lst ed. (London, 1989), 15.

${ }^{5}$ Antoinette Burton, “Who Needs the Nation? Interrogating 'British' History," Journal of Historical Sociology 10, no. 3 (September 1997): 227-48.

${ }_{6}$ The New Oxford World History series began publishing volumes on particular regions, nations, and phenomena in 2010. See also Thomas Bender, A Nation among Nations: America's Place in World History
} 
Europe, to use Dipesh Chakrabarty's phrase, has had much of its origins in the postcolonial and regional histories of South and East Asia, Africa, and Latin America. ${ }^{7}$ While the fields of world and global history have different energies and genealogies, the former challenging the dominance of Euro-American models and the latter preoccupied with historicizing globalization, both have been well established for several decades. ${ }^{8}$ Within the discipline, the phrase "and the world" has become ubiquitous in the naming of books, conferences, and academic positions. In fact, our own historical discipline was a latecomer to the global turn in the humanities and social sciences more broadly, a turn that was predominantly shaped by geography. 9

In that sense, this roundtable joins ongoing conversations and seeks to situate the category of "Britain and the world" in a broader historiographical context. We wish to examine what intellectual landscapes, institutional conditions, and political conjunctures have helped produce it. At the same time, in thinking about longer transnational engagements with the history of Britain, the roundtable asks what then is signified by the articulation of "Britain and the world" as a new field? What do historians of Britain, and indeed, historians of its empire, stand to gain or lose from the promotion of Britain and the world as a field? More specifically, this roundtable asks whether it merely represents an expansion of the geographical frame of British history, or whether it demands a new set of research questions, methodologies, and archives. And if the latter is the case, what new skills, if any, are required to become a historian of Britain and the world? How are we to teach it to undergraduates, let alone graduate students seeking to enter the profession in the different academies of the former British world? And in what ways does becoming a historian of Britain and the world change our understanding of the history of Britain or, for that matter, of the world?

The contributions that follow grapple with these questions from various perspectives and time periods. We have invited historians from different generations, both in Britain and the United States, who have different ways of approaching the history of Britain in an extranational frame. That the category "Britain and the world" emerged in the midst of a global economic recession and expanded further during a period of

(New York, 2006); David Armitage and Sanjay Subrahmanyam, eds., The Age of Revolutions in Global Context, c. 1760-1840 (New York, 2010); Suzanne Desan, Lynn Hunt, and William Max Nelson, eds., The French Revolution in Global Perspective (Ithaca, 2013); Bradley Naranch and Geoff Eley, eds., German Colonialism in a Global Age (Durham, 2014). For recent critical appraisals, see David A. Bell, "Questioning the Global Turn: The Case of the French Revolution," French Historical Studies 37, no. 1 (2014): 1-24; Jeremy Adelman, "What Is Global History Now?, Aeon, 2 March 2017, https://aeon.co/ essays/is-global-history-still-possible-or-has-it-had-its-moment.”

${ }^{7}$ Dipesh Chakrabarty, Provincializing Europe: Postcolonial Thought and Historical Difference (Princeton, 2000).

${ }^{8}$ Patrick Manning, Navigating World History: Historians Create a Global Past (New York, 2003); William H. McNeill and J. R. McNeill, The Human Web: A Bird's Eye View of World History (New York, 2003); Charles Bright and Michael Geyer, "World History in a Global Age," American Historical Review 100, no. 4 (October 1995): 1034-65; Geoff Eley "Historicizing the Global, Politicizing Capital: Giving the Present a Name," History Workshop Journal 63, no. 1 (Spring 2007): 154-88.

${ }_{9}^{9}$ Doreen Massey, Space, Place and Gender (Minneapolis, 1991); Robin Cohen and Paul Kennedy, Global Sociology (New York, 2000); Paul Jay, Global Matters: The Transnational Turn in Literary Studies (Ithaca, 2010); Jill H. Casid and Aruna D'Souza, eds., Art History in the Wake of the Global Turn (Williamstown, 2014). 
intense nationalism and nativism (especially dominant in Britain, Europe, and the United States) seems more than coincidental. In this moment, at this juncture, therefore, it seems particularly pertinent to open some of these questions to the field as a whole. Rather than provide an exhaustive or prescriptive discussion, our hope is that this roundtable will open up a broader conversation about the changing nature, the possibilities, and the shortcomings of what "Britain and the world" might mean to writing British history.

\section{AND WHAT?}

\section{Miles Ogborn}

In an essay entitled just "And," the Brazilian anthropologist Eduardo Viveiros de Castro writes of "this little magic word ... whose function is to oppose the absence of relation, but without specifying any relation in particular." As he continues, "And" covers all thinkable connections, and therefore allows one to say all sayable things about the terms it connects-which naturally does not demand the work of a specialist."10 Sometimes, I want to suggest, in writing British history, or in doing British studies, the way that the formulation "Britain and the world" argues for all thinkable connections without specifying any particular one can be just what is needed. It might also be an advantage to not be a specialist. Using "and" does, however, have consequences.

In part, writing this is an act of reflection, maybe even self-justification. Ten years ago, I wrote a book on Britain's changing place within the new world of global connections made between the sixteenth and eighteenth centuries. It was a book that in the end was called Global Lives: Britain and the World, 1550-1800." The "global lives" part of the title was to signal that the book works through forty-two short biographical sketches of individual people, from Queen Elizabeth I to an African man on an Atlantic slave ship in 1789 who, during a shipboard revolt, captured a gun and killed the captain-taking in figures such as Pocahontas, William Jones, and Olaudah Equiano on the way. ${ }^{12}$ The subtitle-Britain and the World, 1550-1800was produced more by negation than as a positive statement. It was a formulation that emerged from avoiding terms I did not want to use to describe what I was doing. I avoided the terms global historical geography or historical geographies of globalization, which I had previously used elsewhere to discuss the same ideas. ${ }^{13}$ This was in part because I did not want to limit the audience for the book to other historical geographers or to confuse historians who might never have met one. (I save discussion of the problems with the term spatial history for another time.)

\footnotetext{
${ }^{10}$ Eduardo Viveiros de Castro, "And," in The Relative Native: Essays on Indigenous Conceptual Worlds (Chicago, 2016): 39-54, at 40.

${ }^{11}$ Miles Ogborn, Global Lives: Britain and the World, 1550-1800 (Cambridge, 2008).

${ }^{12}$ For a while, and in response to one of the publisher's readers, the book's main title was going to be "Global Lives, Global Encounters," but I was always convinced that "global lives" should be able to capture multiple ways in which individuals experienced global processes.

${ }^{13}$ Miles Ogborn, "Historical Geographies of Globalisation, c. 1500-1800," in Brian J. Graham and Catherine Nash, eds., Modern Historical Geographies (London, 2000): 43-69. I also taught an undergraduate course called Global Historical Geography, on which the book was based.
} 
It was also because the book was not a work of "global history" in simple terms of coverage nor as intellectual lineage. The book had started life as "Global Lives, 14921800 ," which demonstrates ambition, if nothing else. But as the proposal's reviewers pointed out, and I quickly recognized, it had a particular geography. There were large parts of the globe-particularly in Asia (China was mentioned by one reviewer), Africa, and the Americas south of the Caribbean, but also Europe-that had only a very marginal place in the book. Moreover, as I told the publisher, the book would be about a particular set of relations; it was a work of "British studies," and I could not adequately cover the Spanish, Portuguese, French, Dutch, and Danish as well. So it needed a title that recognized these spatial and temporal limits. Right at the time these decisions were being made, I was reviewing for History Workshop Journal Linda Colley's Captives, with its subtitle Britain, Empire and the World, 1600-1850.14 But I considered that including "empire" or "imperial" in my own title would have suggested two problematic relations that I explore further here: the centrality of empire to understanding relationships between Britain and the world for the period as a whole, and a stronger distinction between "Britain" and "empire" in "the world" than I wanted to assert. It was better, I thought, to make the little magic word, the zero-relator "and," carry the whole burden. Better for the nonspecialist to not specify.

In part, the use of "and" and the avoidance of "empire" were responses to significant historical and geographical changes in the early modern period, up to 1800 . It matters that, in some important ways, neither "Britain" nor "the world" (perhaps "its world" would be better, although understood in terms of connection and experience rather than possession) existed at the beginning of the period in the same way that they existed at its end. The formation of "Britain" as a political entity was part of the process of engagement with the world, whether in terms of sovereignty and the Act of Union in 1707 or questions of British national identity. ${ }^{15}$ The world, as seen from Britain, was also in formation. I began the book with a discussion of Herman Moll's early eighteenth-century map of "the Whole World" (figure 1), which, unlike later iconic maps of Britain, empire, and the world, is not centered on the British Isles (which here are firmly part of Europe); it presents an incomplete whole world, shading off into obscurity at the edges; and it requires careful searching to find the "English Em[pire]" in North America. ${ }^{16}$ Even if, as part of a book title, "Britain and the world" had to invoke as complete these entities for a period when they were at best in formation, the notion did allow for a starting point where, as John Brewer put it, Britain was "a peripheral power-a minor, infrequent and almost inconsequential participant in the great wars that ravaged sixteenth and

${ }^{14}$ Linda Colley, Captives: Britain, Empire and the World, 1600-1850 (London, 2002), which I reviewed in "Gotcha!," History Workshop Journal 56 (Autumn 2003): 231-38.

15 David Armitage, "Making the Empire British: Scotland in the Atlantic World, 1542-1707," Past and Present 155, no. 1 (May 1997): 34-63; Linda Colley, Britons: Forging the Nation, 1707-1837 (New Haven, 1992); Kathleen Wilson, This Island Race: Englishness, Empire and Gender in the Eighteenth Century (London, 2003).

${ }^{16}$ Felix Driver, however, shows that even the most iconic maps of high empire are more complex artifacts than they have been taken for. Felix Driver, "In Search of the Imperial Map: Walter Crane and the Image of Empire," History Workshop Journal 69, no. 1 (Spring 2010): 146-57. 


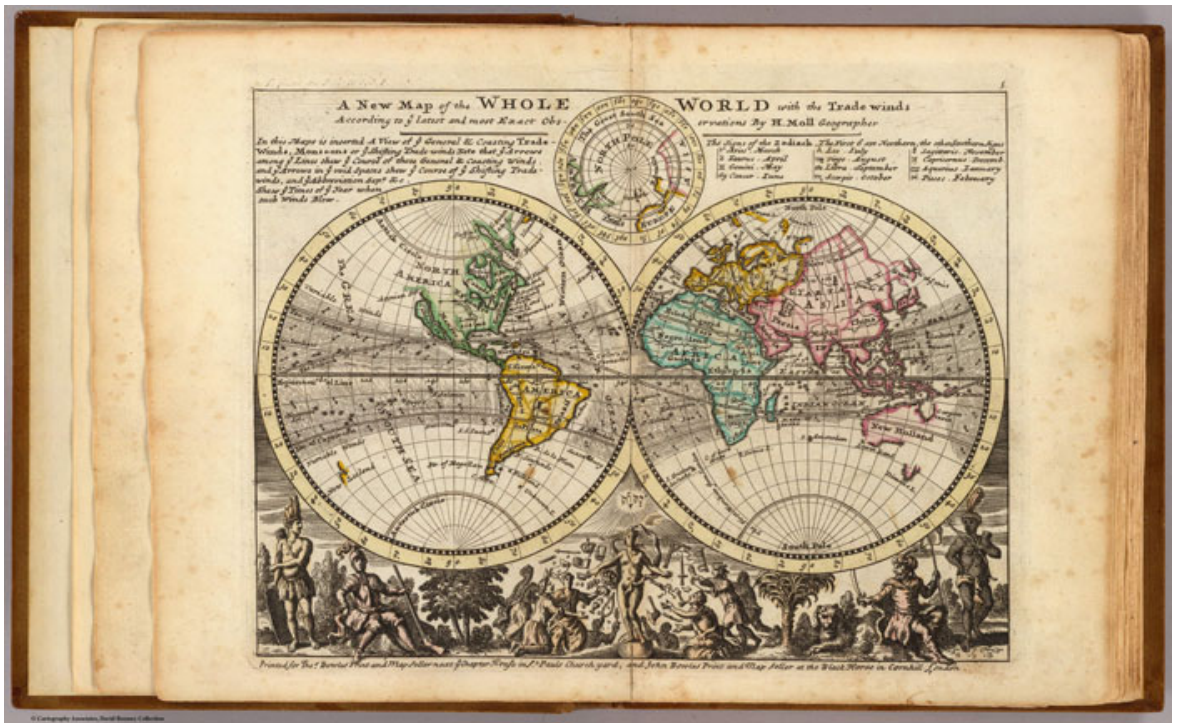

Figure 1-A New Map of the Whole World, by Herman Moll (1736). Courtesy of the John Carter Brown Library at Brown University.

seventeenth-century Europe."17 In turn, not defining Britain and the world in terms of "empire" was a recognition both that to do so was simply not true for much of the early modern period (except maybe in the mind of John Dee) and that accounting for how that changed, which was Brewer's purpose too, always needed to be aware of the historical and geographical limits of empire ${ }^{18}$ _ historical in that what I was arguing for in that book and elsewhere was a non-teleological history of empire akin to the histories of British state formation that were being written at the time, and geographical in that "empire" was a specific relation between Britain and some, both limited and shifting, parts of the world. ${ }^{19}$ Most importantly, these limits meant that "empire" always had to be understood as just one set of "all [the] thinkable connections" - of trade, labor, piracy, encounter, scientific discovery-between Britain and the world that were not simply exhausted or encompassed by it. The usefulness of the formulation "Britain and the world" was in "localizing" or "provincializing" Britain and radically multiplying the sorts of relationships that it had "in the world." 20

The second reason to avoid using "empire" in my title was, perhaps paradoxically, to avoid separating out what might be matters relating to Britain and what to empire.

${ }^{17}$ John Brewer, The Sinews of Power: War, Money and the English State, 1688-1783 (New York, 1989), xiii.

${ }^{18}$ Glyn Parry, "John Dee and the Elizabethan British Empire in Its European Context," Historical Journal 49, no. 3 (September 2006): 643-75.

${ }^{19}$ Miles Ogborn, Indian Ink: Script and Print in the Making of the English East India Company (Chicago, 2007); Michael J. Braddick, State Formation in Early Modern England, c. 1550-1700 (Cambridge, 2000).

${ }^{20}$ The terminology combines that of Bruno Latour, Science in Action: How to Follow Scientists and Engineers through Society (Cambridge, MA, 1987) and Dipesh Chakrabarty, Provincializing Europe. 
Following Kathleen Wilson's account of empire in eighteenth-century British politics, and a range of accounts of the produce of empire in English cultural politics (as well as in contemporary social theory on questions of culture and globalization), the book aimed to signal that lives might be in some way "global"—and covered by the "and"- even if people hardly moved at all. ${ }^{21}$ Britain, then, was itself constituted, for good or ill, by its relations to the world. For example, I had in mind discussions such as that of luxury from the London magazine the Macaroni Jester in the early 1770s, which described London as "the great Mart of the World," a place where

a man who has money, may have at once every delicate, every dainty, and every ornamented Beauty of the four Quarters of the World. Asia, Europe, Africa, and America, are cultivated and ransacked to indulge the Inhabitants in every luxury; and when this Island shall be conquered and depopulated, how will the rising World wonder at the luxurious Lives which English Peasants led, when they are informed, that their common Drink was composed of a Plant which grew in China, drawn with hot Water, and mixed with the Juice of the West India Sugar-cane made into a hard Consistence; and that Liquor was called Tea!22

Reading this alongside Stuart Hall's famous (at least to cultural geographers) account of Englishness, Jamaican sugar, migration, and the cup of tea is a reminder that the world, and particularly the empire, was crucial to the making of Britain, and of British history. ${ }^{23}$ This is not, however, to engage in unhelpfully totalizing arguments about whether or not these relationships were either all-pervasive or insignificant. Instead, opposing the absence of relation and opening up all possible relations, strong and weak, meant that the task was to specify those who considered themselves "citizens of the world," those who might have given the world beyond Britain's shores very little thought, and, at least in theory, everyone in between, and how that changed over time. ${ }^{24}$ Again, this perspective radically multiplies the range of relations that come under consideration.

Yet while "Britain and the world" carries with it a pluralizing and localizing impulse for writing British history, that impulse is always in tension with two

${ }^{21}$ Kathleen Wilson, The Sense of the People: Politics, Culture and Imperialism in England, 1715-1785 (Cambridge, 1995); James Walvin, The Fruits of Empire: Exotic Produce and British Taste, 1660-1800 (London, 1997); see also work such as Avtar Brah, Cartographies of Diaspora: Contesting Identities (London, 1996) and her concept of "diaspora space." This was also the reason for dropping "Global Encounters" from the title (see above note 12).

${ }^{22}$ Quoted in Miles Ogborn, Spaces of Modernity: London's Geographies, 1680-1780 (New York, 1998), 138.

${ }^{23}$ Stuart Hall, "Old and New Identities, Old and New Ethnicities," in Anthony D. King, ed., Globalisation and the World System (London, 1991), 42-68; Doreen Massey, "A Global Sense of Place," Marxism Today 33 (June 1991): 24-29.

${ }^{24}$ For quite different eighteenth-century "citizens of the world" in London, see Vincent Carretta, Equiano, the African: Biography of a Self-Made Man (Athens, 2005), and David Hancock, Citizens of the World: London Merchants and the Integration of the British Atlantic Community, 1735-1785 (Cambridge, 1995). For a discussion of European indifference to the Americas, see Trevor Burnard's reply in the forum on his book Planters, Merchants, and Slaves in Journal of Early American History 5, no. 3 (November 2015): 271-310, at 301. For a detailed account of how and why abolitionists tried to make the Atlantic world matter to more people in Britain, see Christopher L. Brown, Moral Capital: Foundations of British Abolitionism (Chapel Hill, 2006), and for a later period, see Catherine Hall, Civilising Subjects: Metropole and Colony in the English Imagination, 1830-1867 (Cambridge, 2002). 
countertendencies. The first is that as a geographical framing it makes a strong claim for the importance of understanding Britain if we are to understand "the world." This is a claim that has run through justifications for studying British history as the history of constitutional democracy, economic change, imperial power (and weakness) and, perhaps the latest, global environmental change (as the Anthropocene is traced back to James Watt's steam engine, or even to 1610 and the regrowth of American forests with massive Indigenous population decline, which date seems to symbolically signal Jamestown more than Columbus's landfall). ${ }^{25}$ While there is clear merit in addressing Britain's world historical role, it would be problematic if it became the only story or if the counterparts to this way of writing history were multiple similar formulations-Portugal and the world, Brazil and the world, Dahomey and the worldnot because the claim of significance cannot be made for these histories but because even their serial combination would obscure the more complex configurations and circulations that need to be understood. ${ }^{26}$ Once the question of how to conceptualize these global historical and geographical patterns has been opened up, however, as it has been for Atlantic history, the tension between localizing and centralizing Britain in these accounts becomes evident. ${ }^{27}$ It is instructive, then, that one important attempt to write a history of Britain, empire, and the worldC. A. Bayly's Imperial Meridian: The British Empire and the World, 1780-1830with its brilliant integration of diverse world-regional histories of capitalism, state and class formation, and ideology and identity, and its focus on the dynamics of pre-colonial Eurasia and Africa as much as on the British Empire or Britain itself, can be seen a stepping stone between Bayly's exploration of these dynamics in northern India and his setting out of a truly global historical synthesis in The Birth of the Modern World, 1780-1914. Perhaps this is simply to say that for those who don't have a prior commitment to "British studies," "Britain and the world" may not look like the right starting point at all, and for those who do, it may lead them elsewhere. ${ }^{28}$

The second countertendency is that while "and" might allow one to say all sayable things about Britain and the world, doing so is obviously impossible in practice. Choices have to be made. In Global Lives, the multiplication of relationships considered allowed me to trace the making of Britain's empire as it occurred within a variety of other forms of global connection seen from a range of different positions. In my

${ }^{25}$ On the latter, see Simon L. Lewis and Mark A. Maslin, "Defining the Anthropocene," Nature 519, no. 7542 (March 2015): 171-80; and Frederik Albritton Jonsson, "The Industrial Revolution in the Anthropocene," Journal of Modern History 84, no. 3 (September 2012): 679-96.

${ }^{26}$ I use these examples to indicate how that would separate what is brilliantly combined in James H. Sweet, Domingos Alvares, African Healing, and the Intellectual History of the Atlantic World (Chapel Hill, 2011). For attempts to rethink the geographical configurations of imperial sovereignty, see Lauren Benton, A Search for Sovereignty: Law and Geography in European Empires, 1400-1900 (Cambridge, 2011).

${ }^{27}$ Within a growing literature, see John Thornton, Africa and Africans in the Making of the Atlantic World, 1400-1800 (Cambridge, 1998); David Armitage, "Three Concepts of Atlantic History," in David Armitage and Michael Braddick, eds., The British Atlantic World, 1500-1800 (New York, 2002), 11-27; Miles Ogborn, "Atlantic Geographies," Social and Cultural Geography 6, no. 3 (June 2005): 379-85; and Jorge Cañizares-Esquerra and Benjamin Breen, "Hybrid Atlantics: Future Directions for the History of the Atlantic World," History Compass 11, no. 8 (2013): 597-609.

${ }^{28}$ C. A. Bayly, Rulers, Townsmen and Bazaars: North Indian Society in the Age of British Expansion, 17701870 (Cambridge, 1983); C. A. Bayly, Imperial Meridian; and C. A. Bayly, The Birth of the Modern World, 1780-1914 (Oxford, 2004). 
doing so, a particular turning point around the time of the Seven Years' War became evident, and I was also able to identify patterns in the changing uses of violence across time and space. Overall, it was possible to show how Britain's place in the world was different at the beginning and at the end of the period, to set out how that had dramatically different implications for different people, and to try to conceive an historical geography of global connection that was built by human agents even if not in conditions of their own choosing. In this way, such accounts of Britain and the world draw on traditions of anti-imperial and postcolonial writing on agency, power, and empire, such as that of C. L. R. James, Walter Rodney, Eric Williams, Edward Said, and the Subaltern Studies group. ${ }^{29}$ Yet there is, of course, nothing in the formulation "Britain and the world" to stop others saying other sayable things about the terms it connects. Scholars already have sharp disagreements about the legacies of the British Empire in and beyond Britain, how far Britain was shaped by empire, and which parts of the world Britain's history has connected it to most significantly. ${ }^{30}$ At a time when debates over Britain's place in the worldthe degree to which it is European, should be involved in globalization, or is part of an "Anglosphere"-have (re)appeared in full force, our different historical and geographical accounts of the past matter for how Britain's futures are imagined.

Viveiros de Castro had something particular, and quite literal, in mind when he called "and" a magic word. He describes its function as "a connective which is to the universe of relations as the notion of mana (I mean Lévi-Straussian mana) is to the universe of substances." ${ }^{11}$ Mana is a Pacific islanders' term for the effectiveness with which people "mastered the art of successful exchange in the relational networks" of people and things through which moved the life-force of the ancestor gods. ${ }^{32}$ For Lévi-Strauss, the word came to designate "the unconscious reflex of the human mind to fill the lacaunae in its understanding of the world with a signifier of interchangeable value," something he, in structuralist terms, understood as common to all cultures as they explored their "failure to think and describe the world completely objectively." 33 Since such structuralist universalisms and their dreams of objectivity are beyond us, it might be better to draw on the history and anthropology of how mana, in its broad but cross-culturally inexact affinity with "honor" or "prestige," shaped the relationship between Indigenous people and European voyagers and missionaries in the Pacific through both its "rough common ground" and the confusions and conflicts born of difference. ${ }^{34}$ In this way the

${ }^{29}$ James, The Black Jacobins; Williams, Capitalism and Slavery; Walter Rodney, How Europe Undeveloped Africa (London, 1972); Edward W. Said, Orientalism (New York, 1978); Ranajit Guha and Gayatri Chakravorty Spivak, eds., Selected Subaltern Studies (New York, 1988).

${ }^{30}$ Various debates have revolved around Niall Ferguson, Empire: How Britain Made the Modern World (London, 2003): Bernard Porter, The Absent-Minded Imperialists: Empire, Society, and Culture in Britain (Oxford, 2006); and Andrew Roberts, A History of the English-Speaking Peoples since 1900 (London, 2006).

${ }^{31}$ Viveiros de Castro, "And," 40.

32 Anne Salmond, The Trial of the Cannibal Dog: The Remarkable Story of Captain Cook's Encounters in the South Seas (New Haven, 2003), 430.

${ }^{33}$ Christopher Johnson, Claude Lévi-Strauss: The Formative Years (Cambridge, 2003), 75-76.

${ }^{34}$ Salmond, Trial of the Cannibal Dog, 431; Nicholas Thomas, Discoveries: The Voyages of Captain Cook (London, 2003); Tony Ballantyne, Entanglements of Empire: Missionaries, Maori, and the Question of the Body (Durham, 2014). 
magic word "and" can be taken as an open-ended invitation to explore, imagine, and debate the relations between the terms it connects-Britain and the world-as they came into being, and as they change.

\section{THE WORLDING OF BRITAIN}

\section{James Vernon}

It is tempting to begin by asserting that the worlding of Britain is as old as the British Empire. Certainly, the historiographical expansion of England and the quest for the history of "Greater Britain" or the British world began with the institutionalization of our discipline in the late nineteenth century. ${ }^{35}$ If that project was intrinsically an imperial endeavor, one concerned with maintaining the racialized whiteness of the British Empire, so decolonization and European integration generated renewed debate about the nature and meaning of Britain's history after empire. When J. G. A. Pocock pleaded in 1975 for a new understanding of British history as the product of a broader "Atlantic archipelago," he did so not just to chastise those who had long written insular island stories of the nation. ${ }^{36}$ An impeccable product of the "empire of scholars" who shuffled between England and New Zealand and eventually landed in the United States, Pocock wanted to revive a history of a British world that stretched from the "banks of the Mississippi" to "those of the Waimakariri." It was an elegiac plea for British historians to remember the world they had lost in what Pocock described as a "post-Commonwealth" age. That age was defined by Britain having joined (and failed to leave in the referendum of 1975) the European Economic Community, as well as the potential breakup of Britain as "the Troubles" raged in Northern Ireland, and Scottish and Welsh nationalists pushed for devolution. ${ }^{37}$ Pocock's argument for a history of the Britain's former white world was one that resonated at a moment when the migration of Commonwealth citizens of color had inflamed a vitriolic English nationalism that was skillfully harnessed by the emergent politics of Thatcherism. ${ }^{38}$

Of course, Pocock's lament for the lost British world was not alone responsible for encouraging historians of Britain to take flight from the nation as their object. The proliferation of new subdisciplines like social, urban, and women's history historicized other objects of study that were often pursued in local as opposed to national contexts and also sometimes invited cross-national comparison. There was also a profusion of work that established, as Pocock had done, new geographical frames for

\footnotetext{
${ }^{35}$ See Duncan Bell, The Idea of Greater Britain: Empire and the Future of the World Order, 1860-1900 (Cambridge, 2007); Tamson Pietsch, Empire of Scholars: Universities, Networks and the British Academic World (Manchester, 2013); and Amanda Behm, Imperial History and the Global Politics of Exclusion: Britain, 1880-1940 (London, 2018). The following paragraphs draw from James Vernon, "The History of Britain Is Dead; Long Live a Global History of Britain," History Australia 13, no. 1 (May 2016): 19-34.

${ }^{36}$ J. G. A. Pocock, "British History: A Plea for a New Subject," Journal of Modern History 47, no. 4 (December 1975): 601-21.

${ }^{37}$ Pocock, "British History," 620, 621.

${ }^{38}$ Camilla Schofield, Enoch Powell and the Making of Postcolonial Britain (Cambridge, 2013); Kennetta Hammond Perry, London Is the Place for Me: Black Britons, Citizenship, and the Politics of Race (Oxford, 2016).
} 
situating "British" history. What was called a "new British history" emerged from work on the intersection of the early modern "four kingdoms" that called into question the old view of English imperial dominance over Scotland, Ireland, and Wales. ${ }^{39}$ Yet while histories of the four kingdoms made British history polycentric, they remained centered around the British Isles. Atlantic history, with its interest in the traffic of goods, peoples, and ideas across an ocean region, expanded the geographical frame. The Atlantic history envisaged by Pocock, and practiced by Bernard Bailyn and by Jack Greene (Pocock's colleague at Johns Hopkins), gradually moved beyond its initial Anglo-colonial, North American orientation to include Europe and the Americas as a whole, as well as the continent of Africa and the Caribbean. ${ }^{40}$ Meanwhile, the history of Britain, often traditionally conceived as the history of the English state, was also increasingly placed in a broader European context. This took the form of either resituating Britain in relation to the broader history of the continent or employing an explicitly comparative method where Britain became one of several "national" cases. ${ }^{41}$ Much of this scholarship appeared to explain and even repudiate the hostility to European integration that gripped British political culture from the 1980s.

Many of these debates were eclipsed in the 1990s by the development of a "new imperial history." 42 Here again, as with so many of these historiographical flights from the nation, the new imperial history was largely not made in Britain. The culture wars in the North American academy, the influence of Said's Orientalism, and the rethinking of South Asian history by the Subaltern Studies Collective allowed British history itself to be understood as an imperial formation. ${ }^{43}$ When it was taken up in Britain, it was energized by a different set of concerns: namely, the attempt to unsettle Britons' amnesia about empire and to grapple with the continuing hold of racialized forms of politics in a multiethnic and multifaith

${ }^{39}$ Conrad Russell, "The British Problem and the English Civil War," History 72, no. 236 (October 1987): 395-415; Hugh Kearney, The British Isles: A History of Four Nations (Cambridge, 1989); Brendan Bradshaw and John Morrill, eds., The British Problem c. 1534-1707: State Formation in the Atlantic Archipelago (New York, 1996); Raphael Samuel, "British Dimensions: 'Four Nations History," History Workshop Journal 40, no. 1 (Autumn 1995): i-xxii.

${ }^{40}$ For good overviews, see David Armitage and Michael Braddick, eds., The British Atlantic World, 1500-1800 (London, 2002); Jack Greene and Philip D. Morgan, eds., Atlantic History: A Critical Appraisal (Oxford, 2009). See also Paul Gilroy, The Black Atlantic: Modernity and Double Consciousness (Cambridge, MA, 1993).

${ }^{41}$ Jonathan Clark, English Society, 1660-1832: Religion, Ideology and Politics during the Ancien Regime (Cambridge, 1985); John Brewer, Sinews of Power: War, Money and the English State, 1688-1783 (Cambridge, MA, 1990); Colley, Britons; Susan Pedersen, Family, Dependence and the Origins of the Welfare State: Britain and France, 1914-1945 (Cambridge, 1995); Deborah Cohen, The War Come Home: Disabled Veterans in Britain and Germany, 1914-1939 (Oakland, 2001); Deborah Cohen and Maura O'Connor, eds., Comparison and History: Europe in Cross National Perspective (London, 2004).

${ }^{42}$ Antoinette Burton, After the Imperial Turn? Thinking with and through the Nation (Durham, 2003); Dane Kennedy, "The Imperial History Wars," Journal of British Studies 54, no. 1 (January 2015): 5-22; Durba Ghosh, "Another Set of Imperial Turns," American Historical Review 117, no. 3 (June 2012): 772-93.

${ }^{43}$ Said, Orientalism; Guha and Spivak, eds., Selected Subaltern Studies; Antoinette Burton, Burdens of History: British Feminists, Indian Women and Imperial Culture, 1865-1915 (Chapel Hill, 1994); Ann Laura Stoler and Frederick Cooper, eds., Tensions of Empire: Colonial Cultures in a Bourgeois World (Oakland, 1997); Kathleen Wilson, ed., A New Imperial History: Culture, Identity and Modernity in Britain and the Empire, 1660-1840 (Cambridge, 2003). For historians of Britain, Burton's "Who Needs the Nation?" quickly became iconic. 
postimperial nation. ${ }^{44}$ Despite the differing investments of its locales of production, the new imperial history undertook to demonstrate that it was impossible to separate the histories of Britain and its empire because they were, politically and culturally, mutually constitutive of each other.

By the late 1990s, with globalization talk rife, there were distinct signs of a shift toward the worlding of British history. ${ }^{45}$ In 1999, Catherine Hall and Linda Colley began the influential seminar "Reconfiguring the British: Nation, Empire, World 1600-1900" at the Institute of Historical Research in London. That same year the NACBS Report on the State and Future of the Field argued that British history in North America was experiencing a crisis, with fewer jobs, students, and research grants. ${ }^{46}$ With reduced funding for higher education at the end of the Cold War and the culture wars of the 1980s, the report suggested, history departments were recalibrating by turning away from the dead white males of western "civilization" toward previously neglected world histories. The report concluded that to remain viable in North America, the field of British history had to be presented as an imperial and global story so that it could provide "an avenue of inquiry into the larger processes that have transformed the globe and the relations among its inhabitants." 47

Almost two decades later, the practice of British history has itself been transformed by the imperial, transnational, and global turns. However, outside of the United Kingdom, where over 40 percent of historians who find jobs continue to study "British" history, this worlding of the field has not replenished jobs. ${ }^{48}$ Indeed, following the Great Recession, as disinvestment from higher education accelerated, the job market in the United States worsened in almost all fields. ${ }^{49}$ It is probably no coincidence that the number of "in the world" positions across diverse Euro-America fields has grown as departments are downsized or "rightsized." Increasingly, those lucky enough to be hired on a tenure track are asked to teach not just world history but

${ }^{44}$ Catherine Hall, ed., Cultures of Empire: Colonisers in Britain and the Empire in the Nineteenth and Twentieth Centuries (London, 2000); Catherine Hall, Civilizing Subjects: Metropole and Colony in the English Imagination, 1830-1867 (Chicago, 2002). See also Philippa Levine, ed., Gender and Empire: Oxford History of the British Empire (Oxford, 2004); Bill Schwarz, White Man's World (Oxford, 2011).

${ }^{45}$ On globalization talk, see Frederick Cooper, Colonialism in Question: Theory, Knowledge, History (Berkeley, 2005), chap. 4.

${ }^{46}$ North American Conference on British Studies, NACBS Report on the State and Future of British Studies in North America (1999), http://www.nacbs.org/archive/nacbs-report-on-the-state-and-future-ofbritish-studies. This story of decline was also evident in Australia; see Wilfred Prest, "British History in Australia over Two Centuries," Australian History Association Bulletin 89 (December 1999): 42-60. For a fuller discussion, see Leigh Boucher and Kate Fullagar, "British History from the Antipodes," History Australia 13, no. 1 (May 2016): 6-18.

${ }^{47}$ NACBS Report.

${ }^{48}$ Luke Clossey and Nicholas Guyatt, 'It's a Small World after All: The Wider World in Historians' Peripheral Vision,” Perspectives on History 51, no. 5 (May 2013), https://www.historians.org/publications-and-directories/perspectives-on-history/may-2013/its-a-small-world-after-all.

${ }^{49}$ Robert B. Townsend and Julia Brookins, "The Troubled Academic Job Market for History," Perspectives on History 54, no. 2 (February 2016), https://www.historians.org/publications-and-directories/perspectives-on-history/february-2016/the-troubled-academic-job-market-for-history. The data for the United Kingdom is less easily available, but what we have shows that while the number of positions have actually increased since 2008 , they are dwarfed by the exponentially rising number of new PhDs. Brodie Waddell, "Students, PhDs, Historians and Jobs, 1994-95 to 2014-15," The Many-Headed Monster (blog), 29 February 2016, https://manyheadedmonster.wordpress.com/2016/02/29/studentsphds-historians-and-jobs-199495-201415-feb-2016-update/. 
across regional fields as so-called "twofers." However else we understand the field of Britain and the world, it is clearly part of the institutional landscape created by the neoliberal restructuring of universities. That is to say, it is a field that is here to stay for a while. What then is it?

There appear to be at least three different, if sometimes overlapping, approaches to being a historian of Britain and the world. I characterize them as

- an imperial history of the British world as itself an object;

- a history of the worlding of Britain, that is, the growing consciousness of the world among Britons; and

- a global history of Britain concerned with how the world made Britain.

In what follows, I am primarily concerned with Britain and the world in the modern period. Although I can see ways in which these approaches can also characterize the early modern world, I do not wish to refuse the alterity of other processes and relationships.

\section{Imperial Histories of the British World}

Here "the British world" signifies the British Empire as well as Britain's influence further afield in the so-called informal empire made possible by its capital flows, military might, and trading reach. The late nineteenth-century advocates of a "Greater Britain" may have first imagined this history, but it was Cain and Hopkins who reanimated it in the late 1980s by tracing the global influence of the City of London in ways somewhat at odds with the new imperial history. ${ }^{50}$ Whereas the new imperial historians sought to keep the mutually constitutive relationship between metropole and colony in view through cultural histories of difference, historians of the British world turned to how patterns of white settlement, trade, military endeavor, and transport and communication systems forged a new Anglosphere in ways that often ignored racialized violence against Indigenous populations. It was a turn self-consciously taken to reassert the importance of colonies of "settlement" over those of "conquest," or of the "dominions" over the "dependent" colonies. ${ }^{51}$ This version of Britain and the world is now probably most closely associated with the work of John Darwin and James Belich, but it is also promoted by the British Scholar Society and its journal, Britain and the World.$^{52}$ Leaving aside the definitional imprecision of what precisely constitutes this British world, these various strategies for the "worlding" of British history tend to reconstitute an Anglosphere imperialism in which white people (mainly men) and an Anglo-oriented political and economic

${ }^{50}$ P. J. Cain and A. G. Hopkins, "Gentlemanly Capitalism and British Overseas Expansion I: The Old Colonial System, 1688-1850,” Economic History Review 39, no. 4 (November 1986): 501-25; P. J. Cain and A. G. Hopkins, "Gentlemanly Capitalism and British Overseas Expansion II: New Imperialism, 1850-1945," Economic History Review 40, no. 1 (February 1987): 1-26. See also P. J. Cain and A. G. Hopkins British Imperialism: Crisis and Deconstruction, 1914-1990 (London, 1993).

${ }^{51}$ Carl Bridge and Kent Fedorowich, eds., The British World: Diaspora, Culture, and Identity (London, 2003); Phillip Buckner and R. Douglas Francis, eds., Rediscovering the British World (Calgary, 2005).

${ }^{52}$ Britain and the World was first published in 2008. The following year saw the publication of John Darwin, The Empire Project: The Rise and Fall of the British World System, 1830-1970 (Cambridge, 2009); and James Belich, Replenishing the Earth: The Settler Revolution and the Rise of the Anglo-World, 1783-1939 (Oxford, 2009). 
culture once again take center stage in their self-appointed role as guardians of the world. ${ }^{53}$ Indeed, we are all now attuned to the ways in which ideas of imperial federation and transcolonial cooperation germinated the varied forms of internationalism after the Great War. ${ }^{54}$ There is growing concern that these approaches to the history of Britain and the world occlude what Antoinette Burton refers to in the title of her 2015 book: The Trouble with Empire. ${ }^{55}$ Certainly those working on settler colonialism in the British world have been at pains to write back in the histories of Indigenous peoples, just as recent work on interwar internationalisms have provided path-breaking corrections to the white, Anglo, and masculine nature of that project. ${ }^{56}$

\section{Worlding Britain}

A quite different approach is taken by those interested in Britain's consciousness of, and engagement with, the world. The preoccupation of much of this work has been to reclaim a cosmopolitan history of Britons that can offset the more familiar histories of xenophobia, racism, nationalism, and imperialism. Think of the trajectory of Linda Colley's work from Britons (1993) to The Ordeal of Elizabeth Marsh (2008). At its worst, this approach amounts to a type of trainspotting of Britons in the world, but at its best it recovers the dense network of association and affiliation that allowed Britons to imagine and act in the world. Indeed, in the arguably foundational texts published by Colley and Ogborn in 2008, a central question was how individuals experienced and helped shape global historical processes. ${ }^{57}$ Interestingly, in contrast, much of the subsequent work has tended to stress structure over agency, in part because it has been animated by the ways in which from the late nineteenth-century rail, steamships, and telegraph shrank the world and helped forge a new sense of global community. ${ }^{58}$ It is here that I would locate the burgeoning histories of humanitarianism and human rights, the new histories of anticolonialism and internationalism, the growing interest in Britain's global role after decolonization, and the rise of global consumer and protest movements from the 1950s. ${ }^{59}$ Much of this work is

${ }^{53}$ Rachel K. Bright and Andrew Dilley, "After the British World," Historical Journal 60, no. 2 (June 2017): 547-68.

${ }^{54}$ Bell, The Idea of Greater Britain; Mark Mazower, No Enchanted Palace: The End of Empire and the Ideological Origins of the United Nations (Princeton, 2009); Susan Pedersen, The Guardians: The League of Nations and the Crisis of Empire (Oxford, 2015).

${ }^{55}$ Dane Kennedy and Gregory Barton, "Debating the 'Global History of Britain," Perspectives on History 51, no. 2 (February 2013); Priya Satia, "Guarding the Guardians: Payoffs and Perils," Humanity 7, no. 3 (Winter 2016): 481-98.

${ }^{56}$ See for example, Ballantyne, Entanglements of Empire; Alan Lester and Zoe Laidlaw, eds., Indigenous Communities and Settler Colonialism: Land Holding, Loss and Survival in an Interconnected World (New York, 2015); Lisa Lowe, The Intimacies of Four Continents (Durham, 2015); Mrinalini Sinha, Specters of Mother India: The Global Restructuring of an Empire (Durham, 2006); Marc Matera, Black London: The Imperial Metropolis and Decolonization in the Twentieth Century (Oakland, 2015).

${ }^{57}$ Linda Colley, The Ordeal of Elizabeth Marsh (New York, 2008); Ogborn, Global Lives.

${ }^{58}$ Gary Magee and Andrew Thompson, eds., Empire and Globalisation: Networks of People, Goods and Capital in the British World, c. 1850-1914 (Cambridge, 2010); Tony Ballantyne and Antoinette Burton, Empires and the Reach of the Global, 1870-1945 (Cambridge, MA, 2014).

${ }_{59}$ Matthew Hilton, Prosperity for All: Consumer Activism in an Era of Globalization (Ithaca, 2009); Jordanna Bailkin, Afterlife of Empire (Berkeley, 2012); Emily Baughan, "Every Citizen of Empire Implored to 
being developed by a new generation of scholars who are opening up fresh archives in Britain from the nongovernmental organizations involved in these campaigns. Only some, indeed too little, of this work is being generated by those conducting research across several continents, sometimes using multiple languages. While there is certainly a risk that some of this work reinscribes a myth of Britain's liberal exceptionalism, most of it acknowledges the profound influence of imperialism and the racially inflected "universalism" of Britons' consciousness of global community.

\section{Global Histories of Britain}

The third and final approach, the one that informs my current work, is what I call a "global history" of Britain. ${ }^{60}$ Instead of following Britons literally or imaginatively into the world, it explores how Britain was transformed from the outside in by processes and structures that were always already transnational or global in scale. ${ }^{61}$ Just as the new imperial history reminded us that colonial subjects helped shape Britain's history, so this approach reverses the old conceit that Britain made the modern world by instead exploring how the world made Britain. The problem is how best to realize a global history of Britain. There is the vexed question of whether it is possible to train such a scholar and reconcile breadth of study over several regions with indepth knowledge of particular nations and localities. And there is the no less fraught issue of whether such work will only be possible for a very privileged few working in the richest of universities with the capacity to visit archives across the world, acquire the language skills, and/or hire veritable armies of research assistants. The question of how to write the history of Britain and the world in ways that take equally seriously both parts of the equation-"Britain" and "the world" - and yet is not limited to an elite group of actors, institutions, or historians is a profoundly difficult one.

One approach may be to use microhistories as a way of addressing global processes without losing sight of the locales and individuals through which they are lived and shaped. Microhistories also allow us to study those processes with archival depth and specificity. ${ }^{62}$ In the classroom, I have developed a global history of football or soccer as a means of tracing the ways in which the game invented in Britain has been transformed as it spread across the world. My new book project takes Heathrow airport as a point of departure for thinking about a global history of neoliberal Britain in the late twentieth century. Thanks to state investment, Britain's old imperial ties, and

Save the Children!': Empire, Internationalism and the Save the Children Fund in Inter-War Britain," Historical Research 86, no. 231 (February 2013): 116-37; Matera, Black London; Tehila Sasson, "From Empire to Humanity: The Russian Famine and the Imperial Origins of International Humanitarianism," Journal of British Studies 55, no. 3 (July 2016): 519-37.

${ }^{60}$ James Vernon, Modern Britain, 1750 to the Present (Cambridge, 2017).

${ }^{61}$ Significantly, this is an approach that has been pioneered by scholars who are not historians of Britain. See Williams, Capitalism and Slavery; Kenneth Pomeranz, The Great Divergence: China, Europe and the Making of the Modern World Economy (Princeton, 1999); Timothy Mitchell, Carbon Democracy: Political Power in the Age of Oil (London, 2011); Adam Tooze, The Deluge: The Great War and the Remaking of the Global Order (New York, 2014); Sven Beckert, Empire of Cotton: A Global History (New York, 2015).

${ }^{62}$ Brodie Waddell, "What Is Microhistory Now?," The Many-Headed Monster (blog), 20 June 2017, https://manyheadedmonster.wordpress.com/2017/06/20/what-is-microhistory-now/. 
the growth of commercial air freight and travel from the 1960s, Heathrow became the site where the world came to Britain and from which Britons traveled the world in increasing numbers. Between 1965 and 2011, the number of its passengers increased sevenfold to 70,000,000, its cargo business grew sixfold to $1,579,000$ tons, and the number of those employed there doubled to $75,000 .{ }^{63}$ In 1968 , Heathrow had just one terminal; its fifth was opened in 2008. The state agency established in 1965 to govern Heathrow (and Britain's other airports) was privatized in 1986, as was its principal air carrier, British Airways, in 1987. Both are now owned and operated by overseas companies.

The expansion of Heathrow and its privatization has been, and remains, hugely contentious. Trade unionists have protested intensification, layoffs, and casualization. Environmentalists and local residents have sought to prevent noise pollution and halt construction of new terminals and runways. Civil liberties and human rights groups have condemned the proliferation of security measures and privately operated detention centers for refugees and illegal immigrants around the airport. These processes and debates are not autarchic to the British variant of neoliberalism; they have been forged by global processes that make possible flows of capital, fuel, aircraft manufacturing, security and management systems, travelers, migrants, workers, and protestors.

I conclude by returning to the often troubling intellectual, institutional, and political conditions from which the field of Britain and the world has emerged. It is not just a question of who gets to research and write the history of Britain and the world, while others are left precariously teaching it so that regional specialists do not need to be hired. It is also a question of the degree to which histories of Britain and the world seek to reanimate an Anglo world in which white men invariably occupy center stage and the violence of slavery and colonialism are conveniently forgotten. That is the history currently being promoted by the post-Brexit British government with the hashtag \#GlobalBritain. It is a history that seeks to restore the old trading connections of the imperial British world, seemingly oblivious to the politics of its racial order, let alone the fact that European integration was partly a necessary response to decolonization and the restructuring of the global economy. ${ }^{64} \mathrm{I}$ have tried to suggest that grappling with these histories is one way to chart the present and future possibilities of this strange new field of Britain and the world.

\section{BRITAIN AND THE WORLD: A FIX FOR PROVINCIALISM OR A CASE OF COLONIALISM?}

\section{Priya Satia}

When I started graduate school in the late 1990s, being an imperial historian of modern Britain was still "new." As the twentieth century ended, putting empire at the heart of British history became a trend, fueled by growing awareness of the orientalist liabilities of the scholarly inheritance produced before the 1970s. ${ }^{65}$ One by

\footnotetext{
${ }^{63}$ Philip Sherwood, The History of Heathrow (Stroud, 1999); Sharon Doherty, Heathrow's Terminal 5: History in the Making (Hoboken, 2008); Ian Anderson, Heathrow: From Tents to Terminal (Stroud, 2014).

${ }^{64}$ Duncan Bell, "The Anglosphere: New Enthusiasm for an Old Dream," Prospect, February 2017, https://www.prospectmagazine.co.uk/magazine/anglosphere-old-dream-brexit-role-in-the-world.

65 Said, Orientalism.
} 
one, noted historians of modern Britain began to produce monographs on the imperial dimensions of domestic British history, emphasizing the "mutually constitutive" nature of colony and metropole. It turned out that imperialism and transatlantic bonds had shaped British national identity; culture; religious identity and networks; notions of class, gender, and race; institutions of governance; technological, financial, and economic developments; literature; liberalism; politics-the gamut of major topics and themes in modern British history. One of my teachers, the inimitable Thomas Metcalf, rolled his eyes at this belated acknowledgment of the central rather than peripheral importance of his field. ${ }^{66}$

While the claim that the empire was central to British history remained contested, the accelerating trend made the proposition less and less radical. In Britain, as James Vernon writes, the trend strove to challenge British amnesia about the imperial past and to grapple with the politics of race and identity in postimperial Britain. It was fueled by the New Imperial History and by the rise of global history and the history of capitalism. Methodologically, the resonance of the subaltern school of South Asian history with British social history traditions of writing "history from below" also encouraged the "worlding" of British history. Expanding hires in South Asian, Middle Eastern, and African history fostered productive engagement between these fields and British historians, sharpening the latter's awareness of how global interactions shaped British history, and vice versa. So too did the expansion of thematically defined fields such as legal history and the history of science and technology. ${ }^{67}$ Historians of Africa and South Asia whose explorations of imperial power drew them into the thickets of British and global history-from Caroline Elkins to Partha Chatterjee to C. A. Bayly—also made it increasingly difficult for British historians to remain ensconced in an island setting. ${ }^{68}$ Thinking about Britain through a variety of transnational lenses became normal, a kind of default, especially for historians of Britain living and working in North America. Indeed, the trend can partly be understood as an artifact of the shifting geographical center of the academy from the late twentieth century. Thinking about Britain transnationally makes British history more useful and intelligible to an American student population. One way to get American students to care about British history is to remind them of how it shaped the world - their world now - and how the world shaped the familiar sounds, sights, and literature (especially) through which Americans continue to imagine "Britain." Of late, the imperial, transatlantic, transnational, and global turns have been lumped into a single category, "Britain and the world," an increasingly common rubric for jobs in modern British history. The rubric has a pragmatic appeal in the way it efficiently condenses several trends into a single all-welcoming category. But unsurprisingly, it also raises certain ethical, intellectual, and methodological dilemmas, which I briefly invoke here.

First, the possibilities. Besides the pedagogical advantages of cultivating a more inclusive and cosmopolitan version of British history, especially in and for North

\footnotetext{
${ }^{66}$ See, for example, Thomas Metcalf, Ideologies of the Raj (Cambridge, 1997), and his Imperial Connections: India in the Indian Ocean Arena, 1860-1920 (Berkeley, 2008).

${ }^{67}$ See, for example, the work of Lauren Benton and Daniel Headrick.

68 This work builds on older trends of anticolonial historians challenging metropolitan versions of British history, from Dadabhai Naorji's "drain theory” to Williams's Capitalism and Slavery.
} 
America, the new "Britain and the world" rubric offers other intellectual and ethical payoffs. For instance, it opens up the possibility of telling transnational stories that are not only about Britain's relationship with areas it ruled-however much all its transnational relations were undoubtedly shaped by imperial pursuits. Interactions between Britain and Russia might fall under this category, or British and French West Africa, or Britain and the Philippines, and so on. The new rubric thus promises to cultivate more exhaustive and creative forms of international and diplomatic history. Perhaps more obviously, at this moment studying Britain's relationship with "the world" is urgent, given that the latest major development in Britain's history, the Brexit vote, is precisely about that relationship. Exploring "Britain and the world" is thus substantially a way to understand the present in Britain-a real, urgent, and important problematic in domestic history. The current political climate on both sides of the Atlantic has made any kind of pushback against xenophobia, bigotry, and racism urgently important, and to the extent that "Britain and the world" allows for a more inclusive version of British history, it is helpful in an extremely timely way.

Perhaps most importantly, a more global approach to British history is all to the good insofar as it represents a much-needed corrective to the overly national focus of much British history before the 1990s. That provincialism was itself historically produced, an artifact of the era of decolonization in which that history was written. It was no less natural than the new global turn. British social history emerged from many struggles and motivations, but among them certainly was a search for redemption from imperialism as the British state continued to cling to its bad old ways even as it began to leprously shed its colonial limbs. The "little England" focus of much of that work depended on suppressing the presence of nonwhites and the role of imperialism in Britain's national development in the interest of redefining British identity in terms of the communitarian values of the working class. Indeed, even the provincialism of the eighteenth-century working-class world portrayed by New Left historians (many of them former soldiers with richly cosmopolitan life experience) was exaggerated. ${ }^{69}$ It is important to restore the global dimensions of British history that postwar historiography forgot; this is what makes this trend so important-and controversial-in Britain itself (whatever its pedagogical uses in North America). Greater attention to Wales, Scotland, and Ireland as regions with their own local, and colonial, histories and their own global interactions has also been a useful corrective to the England-as-Britain synecdoche.

In general, insofar as we are politically invested in cultivating more universal than particularistic notions of humanity, the transnational perspective is all to the good. Consolidating national and regional fields enables us to trace common threads that were lost in older, more compartmentalized national rubrics. The grand narratives of capitalism, industrialism, and imperialism were broad historical forces with wide, global impact, and we should study their unfolding that way-while respecting differences in local experiences. The simple fact for British history especially is that

\footnotetext{
${ }^{69}$ I have written at greater length about this in "Byron, Gandhi and the Thompsons: The Making of British Social History and Unmaking of Indian History," History Workshop Journal 81, no. 1 (Spring 2016): 135-70.
} 
Britain was shaped enormously by global interactions and had an enormous role in making the modern world. ${ }^{70}$

That said, the new rubric comes with certain risks. As much as it can help us understand Brexit, it also resonates uncannily with Conservative justifications of Brexit as an opportunity to "embrace the world" and once again be a "Global Britain," as Prime Minister Theresa May put it. Context matters: in this particular moment, "Britain and the world" might reasonably be (mis)read as scholarly validation of such views. Indeed, from a scholarly point of view, the rubric has a worrying potential for reifying notions about Britain's special and permanent place as the center and source of global history. Painting everything outside Britain with a single, undifferentiated wash—“the world"-automatically highlights Britain's historic distinction. Arguably, Chinese or South Asian history has been as globally impactful and as globally shaped, yet we do not (yet) think in terms of rubrics like "China and the world" or "India and the world." A search for expertise in "Britain and the world" may suggest that it doesn't matter what part of the world apart from Britain is examined and may sanction a kind of gratuitous engagement with anything "out there." It is genuinely odd for prospective employers to project a wholly undiscriminating attitude toward what that might be-at worst-a politically unsound kind of political correctness that sees British history as the story of great white men acting out on a global stage. This attitude is particularly concerning where the "Britain and the world" rubric is used to kill two fields with one stone and undermine hiring in fields like South Asia, Africa, or the Middle East-that is, to "cover" British history and one or all of those other fields at once. The result is a kind of scholarly colonialism.

The cost of studying Britain strictly transnationally includes a potential loss of local texture, a sense of place, which is essential to a sense of reality-because even when history is transnational, people are in the places they are in. At a basic level, reading "Britain and the world" as "transnational" history automatically privileges interactions on the national scale over regional or local ones. ${ }^{71}$ And processes like globalization and imperialism produce intensely varying local impacts. Networks may, for instance, open up a means of understanding transregional connections, but their components are embedded in local contexts from which a reckless Britain and the world historian would abstract them at great analytical cost. ${ }^{72}$ Take the Quaker family I have been studying for my book Empire of Guns: the Galtons were part of a transatlantic Quaker network, but their actions and outlook were also deeply shaped by their immediate Birmingham and West Midlands context. The students we are teaching are part of a digital generation whose members are used to abstracting themselves and their ties from the specificity of place. But until recently, people did not experience long-distance connections that way. Understanding the Galtons required delving long and deep into local records and archives as much as in national and metropolitan ones. The task was infinitely more complicated by the fact that

\footnotetext{
${ }^{70}$ See, paradigmatically, Hall, Civilising Subjects; Beckert, Empire of Cotton; Cain and Hopkins, "Gentlemanly Capitalism"; Emma Rothschild, The Inner Life of Empire: An Eighteenth-Century History (Princeton, 2011).

${ }^{71}$ See also Tony Ballantyne, "On Place, Space and Mobility in Nineteenth-Century New Zealand," New Zealand Journal of History 45, no. 1 (April 2011): 50-70.

${ }^{72}$ Hall, Civilising Subjects, is exemplary in its treatment of such local contexts.
} 
transregional connections and circulation and mobility of culture, objects, and people (as much as local particularities and forms of disconnectedness) produced that local context. Thinking explicitly in terms of how global processes like capitalism have produced both space and our notions of space and place is crucial to avoid producing narratives of British history that are cosmopolitan but shallow. ${ }^{73}$ Part of our work as historians is to think and teach about how local contexts have been tied to the wider world in different ways at different times. Insofar as our goal is to capture past or lost human experience, that work is essential. Rather than pander to students' desire for history catering to their present-day sensibilities of global connectedness, our job is to help them value history on its own terms. To do so means eschewing transnational commodity or institutional histories that ignore local context and flatten history in a manner that might perhaps be celebrated in an Internet age but is unfaithful to historical reality. We cannot assume that an international organization had the same significance in Britain as in France when local context crucially shaped responses to and perceptions of such bodies. We cannot assume that a commodity traded globally had the same meaning and role in a West African context as it did in Britain. Moreover, a crucial way to teach against xenophobia is to strengthen our sense of the ties between the local and the global rather than choosing between local and global. We should see them not as choices but complements. And this awareness should shape how we do and evaluate work presented under the rubric "Britain and the world."

While we forge ahead with our cosmopolitan agendas, there is also a risk of inadequately preparing graduate students in the deep literature that we seek to update, which is often rich in local texture. Students need that depth to fully grasp the intellectual and ethical stakes of assembling a more transnational story of the Industrial Revolution or the rise of liberalism. Moreover, at a practical level, familiarity with that literature is crucial to developing a sense of confidence in graduate students so that they feel they are the real article, that they have genuine expertise as British historians. Training students for the best kind of globally oriented British historyrather than the sort that unwittingly winds up celebrating the antics of great white men on a global stage - also requires an emphasis on language skills and the ability to use multiple archives where appropriate. To put it another way, students without such skills should not be encouraged to work gratuitously on "Britain and the world" projects.

I am perhaps proposing a fairly high barrier to entry-which may not be unreasonable, given the constrained market for academic jobs in British history. More to the point, the new rubric arguably leaves plenty of room for straight-up "Britain" work too. In the end, we have to make a case for whatever we do; the mystery we are trying to solve must be apparent, and the stakes and analytical payoff should be significant, whether it is a Britain or a Britain and the world project. Ideally, search committees will recognize a worthy project when they see one, regardless of how global or local it is. The new rubric is suitably porous; used wisely, it will enable departments to cast their nets more widely to bring in the most creative and powerful work. Historians

${ }^{73}$ See, paradigmatically, Doreen Massey, "A Global Sense of Place," in Space, Place and Gender (Minneapolis, 1994), 146-56. Recent work centered on oceans also offers useful guides. See, for instance, Eric Tagliacozzo, Helen Siu, Peter Purdue, eds., Asia Inside Out: Connected Places (Cambridge, MA, 2015). 
hired under this rubric would ideally draw on the insights of their work on interregional histories to ensure that their departments do hire liberally in fields like Africa and South Asia so that they do not become unwitting instruments of scholarly colonialism. As teachers, they would emphasize the way that colonialism shaped the world's modern history, especially in Britain where the cruelties and inequities of the imperial past are still routinely neglected in favor of more forgiving depictions of the empire. Like any methodological choice, transnationalism is not something to be unequivocally celebrated; it must serve a worthy and sensible end.

Our current political climate has made the stakes of teaching critical thinking skills and passing on the humanistic inheritance radically clear. We need to think long and hard about what projects we commit to and to whom we pitch them. Awareness of the high stakes in what we do should also shape how we think about disseminating it. Astonishingly, with a few exceptions, while academic British history has been taking increasingly cosmopolitan turns, popular works on British history have continued to celebrate an altogether quainter and more provincial vision of the British past-and a more uncritical version of the British Empire. It is time to breach that divide and make scholarly historical writing about Britain and the world accessible to a wider readership. That is where it can perform its hardest and most important cultural work, on both sides of the Atlantic, and in the wider postcolonial, Anglophone world.

\section{A TRULY GLOBAL BRITAIN?}

\section{Tehila Sasson}

On 17 January 2017, Theresa May gave a speech that laid out her vision for "a truly global Britain.” It was her first significant speech since becoming prime minister. "I want this United Kingdom to emerge from this period of change stronger, fairer, more united and more outward-looking than ever before," she said. "A country that goes out into the world to build relationships with old friends and new allies alike." Britain's vote to leave the European community, according to May, should be used as an opportunity not for an introspective or nativist turn toward the nation or even locality but rather as an opportunity for an international engagement with the wider world. She used the word "global" more than seventeen times to hammer home this point.

It seems almost impossible to reflect on what the field "Britain and the world" might mean without recalling May's speech. As so many commentators have noted, the speech conjured older tropes of an "Empire 2.0."74 It resonated with much older debates about the nation, empire, and the world. The speech echoed the idea of a "Greater Britain," which Duncan Bell has shown emerged from imperial visions of federalist communities in the late nineteenth and early twentieth centuries. ${ }^{75}$ Paul Gilroy has even suggested that much of the current turn toward the

\footnotetext{
74 "In Full: Theresa May's Article 50 Statement," Telegraph, 29 March 2017; Kehinde Andrews, "Building Brexit on the Myth of Empire Ignores Our Brutal History," Guardian, 7 March 2017.

${ }^{75}$ Bell, The Idea of Greater Britain. See also Bell, "The Anglosphere.” One could even claim, following Mrinalini Sinha's work, that May's vision was entrenched within a gender-based vision to Britain's global engagements with the world. See Sinha, Specters of Mother India.
} 
global in contemporary British politics has its roots in nostalgia around empire and its loss. ${ }^{76}$

And yet these imperial origins were only one of multiple formations that made May's 2017 vision. After all, her speech was given at the World Economic Forum in Davos, a forum that had its origins in the crises of the early 1970s. The brainchild of German-born Klaus Schwab, the World Economic Forum was initially created in 1971 to help European companies compete with American corporations by adopting new management practices that would situate corporations in the political and economic landscape in which they operated. In 1974, after the collapse of the Bretton Woods system (a year after the United Kingdom joined the European Economic Community, and the year before the referendum in which Britons voted to remain in it), the World Economic Forum expanded its agenda to include economic and social issues. This was also the first time it invited political leaders into its ranks. In the years that followed, the World Economic Forum developed into one of the largest forums for neoliberal thought, as well as a neutral meeting space in which bitter opponents could meet, such as South African President F. W. de Klerk and Nelson Mandela, or the Palestine Liberation Organization and Israel. ${ }^{77}$ May's vision of a post-Brexit global Britain at Davos, therefore, was embedded within a history of decolonization, European integration, and the deregulation of macroeconomic policy by the American international order of the late twentieth century. Looking exclusively for the imperial origins of May's vision risks missing some of those broader global contexts.

In what follows, I use May's "truly global Britain" speech to ask a broader question about whether there is an analytical difference between writing a history of "Britain and the world" and a writing a history of the British Empire. While the frame "Britain and the world" has frequently been used in job ads and scholarly works, historians have done little to reflect on the relationship between this frame and British imperial history. The example of May's "truly global Britain" speech, however, demonstrates that writing a global history of Britain may open up a more complex conversation about Britain's multiple formations in which empire is one of many. If "Britain and the world" allows a global approach to British history, it has the potential of being a field that would highlight its imperial formations while also acknowledging transnational transformations beyond it. There are, of course, good reasons why the field has focused on recovering the political, social, and cultural role of the empire in making modern Britain. Similarly, historians of empire have long spoke about imperial formations beyond the binary of metropole and colony. I am not arguing against it, but rather, I wish to expand our conversation and consider how imperial power, rule, and law, too, were embedded within global, as well as local, formations. As one historian recently reminded us, "international, global and

${ }^{76}$ Paul Gilroy, After Empire: Melancholia or Convivial Culture? (London, 2004).

77 Vladimir Kvint, The Global Emerging Market: Strategic Management and Economics (London, 2009), 248; Nick Paumgarten, "Magic Mountain: What Happens at Davos?,” New Yorker, 5 March 2012, https:// www.newyorker.com/magazine/2012/03/05/magic-mountain; Neil Parmar, "Klaus Schwab: Inside the World Economic Forum," Wall Street Journal, 4 September 2014; "Who Is the Man behind the World Economic Forum in Davos?," Le News, 26 January 2015; "WEF and Davos: A Brief History," Telegraph, 18 January 2016; John Thornhill, review of The Fourth Industrial Revolution by Klaus Schwab, Financial Times, 17 January 2016. 
imperial histories are far from mutually exclusive modes of history-writing."78 The imperial was never separated from these multiple scales.

The relationship between global, imperial, and local scales no doubt played a crucial role throughout the modern period (if not also earlier), but in the period my own work engages - the second half of the twentieth century-it can be a particularly productive approach to study British decolonization and the period thereafter. The emergence of a new international order in the interwar period, together with the unraveling of European empires that followed, poses a challenge for many of us who study what the historian Eric Hobsbawm has called "the Age of Extremes." That is, how can we write a history of Britain that accounts for the ways in which it was shaped by these global transformations without simply reproducing accounts of the nation's triumphant or a declinist place within them? Here I echo Antoinette Burton's caution that we should not write a history of the British Empire that fetishizes the centrality of the nation. ${ }^{79}$ Empire (as well as its loss) has been the primary pivot to think about these questions, but I would suggest that a global approach to the history of Britain may offer a more expansive frame that would not negate the imperial but would embed it within other transnational and international as well as local events and processes.

A global history of Britain could draw heavily on the methods and practices of imperial history but nevertheless consider new archives, questions, and narratives that would place imperial and postimperial transformations within both local and international contexts. The emphasis here should be less on a particular directionality or a binary between Britain and "the world" (as James Vernon suggests in his contribution here) and more on expanding our archives and research without privileging certain voices or erasing others from our narratives. "Britain and the world" as a field, in other words, can offer a point of view, a lens, and most importantly, a method-of the archives we read-rather than a specific geography. It does not need to exclusively focus on the Anglosphere and the so-called "British world," nor does it need to tell a triumphant story about Britain's exceptional role in the world. ${ }^{80}$ Writing a global history could embed even the most intimate and local histories and biographies within broader transformations such as global decolonization, the rise of the international order, and growth of transnational movements beyond the state.

A global and international frame is of course not unique to British history, and I am building here on conversations in other fields as well as in other disciplines. Historians of the United States and the world, for example, have recently explored how community development programs in India and the Philippines have shaped debates about development in Harlem in the mid-twentieth century. ${ }^{81}$ Similarly, a historian

${ }^{78}$ Paul A. Kramer, "Power and Connection: Imperial Histories of the United States in the World," American Historical Review 116, no. 5 (December 2011): 1348-91, at 1387.

${ }^{79}$ Burton, "Who Needs the Nation?"

${ }^{80}$ John Darwin, The Empire Project: The Rise and Fall of the British World-System, 1830-1970, (Cambridge, 2009); James Belich, Replenishing the Earth: The Settler Revolution and the Rise of the Angloworld, 1783-1939 (Oxford, 2009).

${ }^{81}$ Daniel Immerwhar, Thinking Small: The United States and the Lure of Community Development, (Cambridge, MA, 2015); Samantha Iyer, "The Paradox of Poverty and Plenty: Egypt, India, and the Rise of U.S. Food Aid, 1870s to 1950s” (Ph.D. diss., University of California, Berkeley, 2014). 
of Central and Eastern Europe, Tara Zahra, has explored the relationship between social and political categories of children, aid, and war in international and transnational framework in Britain, France, Germany, and Czechoslovakia from the interwar to the Cold War. ${ }^{82}$ Global historians have also reminded us that processes we associate with globalization did not mean the erasure of local meanings of time and labor in the Middle East in the late ninetieth century. ${ }^{83}$ These historians have provided us with models that are attuned to local and national contexts, even when they take transnational and global approaches. ${ }^{84}$

What I view as fundamental to each of these global histories have been the archives they deploy and the way they work to embed historical subjects in them. The global and international turn has expanded our focus by using the archives of international organizations. The archives of organizations as diverse as the United Nations, the World Bank, the Food and Agriculture Organization, and the World Health Organization enable us to reconsider the role of Britain and the tail end of its empire in an international perspective. In this context, Susan Pedersen's work on the League of Nations has opened new avenues in British and international histories alike. Her 2015 book The Guardians relies on multiple archives, both national and international, to tell the story of the League of Nations and in the process to reassess in that story the role of the British Empire without assuming its centrality. ${ }^{85}$

And it is not only international archives that have enabled new ways of thinking about the history of twentieth-century Britain. The opening of nongovernmental and charity archives like those of Christian Aid, Save the Children, and Oxfam has allowed a new generation of historians to recover histories of liberal internationalism, of race and of the economy. One example is the burgeoning literature on the history of human rights and humanitarianism, which examined the institutional history of nongovernmental organizations and their role in British politics and the world. While previous generations have examined the role of the nineteenth and early twentieth century imperial state, its proxies, and collaborators, ${ }^{86}$ the new histories of

${ }^{82}$ Tara Zahra, The Lost Children: Reconstructing Europe's Families after World War II (Cambridge, MA, 2011).

${ }^{83}$ Vanessa Ogle, The Global Transformation of Time, 1870-1950 (Cambridge, MA, 2015).

${ }^{84}$ Indeed, as Stuart Hall has long reminded us, "The return to the local is often a response to globalization." Stuart Hall, "The Local and the Global: Globalization and Ethnicity," in Culture, Globalization, and the World-System: Contemporary Conditions for the Representation of Identity, ed. Anthony King (Minneapolis, 1997), 19-40, at 33. This is part of an interdisciplinary conversation in geography, anthropology, and postcolonial studies. See, for example, Massey, Space, Place and Gender; Paul Gilroy's use of "the planetary" in Postcolonial Melancholia (New York, 2010); the spatial aspects in Luce Irigaray, An Ethics of Sexual Difference (New York, 2005); Roland Robertson, "Glocalization: Time-Space and Homogeneity-Heterogeneity," in Mike Featherstone, Scott Lash, and Roland Robertson, eds., Global Modernities (New York, 1995), 25-44; Arjun Appadurai, Modernity at Large: Cultural Dimensions of Globalization (Minneapolis, 1996).

${ }^{85}$ Pedersen's work offers at least two crucial contributions to historians of Britain and the world. First, her story shows how while the Permanent Mandates Commission was intended to reaffirm the place of the British Empire in the international order, the commission de facto created a space for internationalization through its petitions system. Secondly, looking at archives beyond Kew allows Pedersen to reassess Britain's role in this international system after Germany joins the League in 1926. Susan Pedersen, The Guardians.

${ }^{86}$ See for example, Lata Mani, Contentious Traditions: The Debate on Sati in Colonial India (Oakland, 1998); Sanjay Sharma, Famine, Philanthropy, and the Colonial State: North India in the Early Nineteenth Century (Oxford, 2001); James Vernon, Hunger: A Modern History (Cambridge, MA, 2007); Richard 
humanitarianism have explored continuities between imperialism and internationalism even during decolonization through the expertise and practices of nongovernmental agencies. 87 They have added new trajectories of "nongovernmental governance" and expanded our understanding of how British institutions beyond the state have come to shape the international order. ${ }^{88}$ Often, however, these histories have remained largely confined within the binary narrative of formal and informal empire. Thus even when they examine the period of decolonization, they remain focused on accounts of neocolonialism. The roles of nongovernmental agents in continuing the formal imperial mission are certainly important, and many of them did continue to carry the interest of the imperial state. Nonetheless, the archives of international and nongovernmental organizations also help us situate these nongovernmental agents in other processes like the Cold War and changes in the global economy. ${ }^{89}$

In my own work, I have found that that while decolonization was important, it did not by itself account for the transformation of the political and moral economy of humanitarianism between the 1940s and 1980s. The story of the transnational boycotts against Nestlé in the 1970s is a case in point, as it emerges from British nongovernmental and governmental archives such as Oxfam, War on Want, and the Wellcome Library; from American organizations like the Infant Formula Action Coalition; and from international organizations like the World Health Organization and the Food and Agriculture Organization. While the materials at the Wellcome Library demonstrate that medical critique of baby formula had its origins in imperial science of the interwar period, the archives of War on War, World Health Organization, and the Food and Agriculture Organization have shown that it was only after empire that it developed into a large mass movement against multinational corporations, mobilizing ordinary Britons as consumers in the global market. Beginning with a campaign led by the British charity War on Want in the early 1970s, the critique of baby formula was recast as part of the humanitarian problem of hunger and malnutrition in the Third World. As Oxfam's archives show, it built on British

Price, Making Empire: Colonial Encounters and the Creation of Imperial Rule in Nineteenth-Century Africa (New York, 2008); Kevin Grant, A Civilised Savagery: Britain and the New Slaveries in Africa, 1884-1926 (London, 2005); Seth Koven, Slumming: Sexual and Social Politics in Victorian London (Princeton, 2004). Building on these, Alan Lester and Fae Dussart in Colonization and the Origins of Humanitarian Governance: Protecting Aborigines across the Nineteenth-Century British Empire (Cambridge, 2014) have explored humanitarianism as "soft power" of the nineteenth-century imperial state.

${ }^{87}$ See for example, Matthew Hilton, "Charity and the End of Empire: British Non-Governmental Organizations, Africa, and International Development in the 1960s," American Historical Review 123, no. 2 (April 2018): 493-517, and Matthew Hilton et al., "History and Humanitarianism: A Conversation," Past and Present (forthcoming, online only); Emily Baughan, Saving the Children: British Humanitarianism in Europe and Africa, c. 1915-2010 (forthcoming); Erin Bell, "A Most Horrifying Maturity in Crime': Age, Gender and Juvenile Delinquency in Colonial Kenya during the Mau Mau Uprising," Atlantic Studies 11, no. 4 (October 2, 2014): 473-90; Kevin O’Sullivan, "Humanitarian Encounters: Biafra, NGOs and Imaginings of the Third World in Britain and Ireland, 1967-70," Journal of Genocide Research 16, no. 2-3 (July 3, 2014): 299-315.

${ }^{88}$ Didier Fassin and Mariella Pandolfi, Contemporary States of Emergency: The Politics of Military and Humanitarian Interventions (New York, 2010).

${ }^{89}$ The new histories of humanitarianism are, of course, only one case in point. It will be equally interesting to see how historians of migration and citizenship, for example, might use international and nongovernmental archives to resituate the history of British decolonization in a more global framework. 
humanitarian discourse post-Biafra and Bangladesh, as well as on international discussions about development and economic disparities shaped by the New Economic International Order proposals rooted within the political and moral economy of global decolonization. By the late 1970s, as the American archives and the World Health Organization archives demonstrate, the movement against baby formula traveled across the Atlantic and was taken up by a feminist and anti-capitalist critique in the spirit of the late 1960s. The movement became about the rights of Third World mothers as consumers and about limiting the power of multinationals. What was originally a local protest and consumerist boycott in Britain emerges from these archives as a product of multiple formations, including postimperial as well as international ones. ${ }^{90}$

Nonetheless, we should be careful not to fetishize the use of these nongovernmental or international archives. When we use them, we must remember the lessons the New Imperial History taught us about the work of the colonial archives in reproducing forms of knowledge and particular subjects of its history. Just as colonial archives follow a principle of selective organization, so too do nongovernmental and international archives. We need to read these international and nongovernmental archives "against the grain" and destabilize their principle of selection. ${ }^{91}$ Of course, unlike the colonial archive, there is no one node of sovereign power that produces archival categories. But as imperial history read "against the grain" allows the subaltern subject to speak, so a global history of Britain could recover the local lives of those who were shaped by international and global transformations. Consumers, workers, and children were agents as well as subjects of this history, and recovering their voices should remind us that the voices of others they interacted with in the global south were silenced. ${ }^{92}$

While international history has often privileged the role of the experts, diplomats, aid workers, and elites, a global approach to the history of Britain instead could allow us to consider different actors and voices beyond international sphere. In my current book monograph, a global frame allows me to ask how British lives came to participate in a world made global at the end of the imperial order through cultural, economic, and political exchanges. Local and imperial narratives about economic life and humanitarianism, which have been so central to the history of Britain in both early and modern periods, transform when considered in relation to more global and international changes. At the same time, this frame also helped me explore how these global political and economic processes did not simply affect ordinary people but were also shaped by them. A global frame can connect what Michel de Certeau called the practices of everyday life with ideas, institutions, and

\footnotetext{
90 Tehila Sasson, "Milking the Third World: Humanitarianism, Capitalism and the Moral Economy of the Nestlé Boycott," American Historical Review 121, no. 4 (October 2016): 1196-1224.

${ }^{91}$ Jacques Derrida, Archive Fever: A Freudian Impression (Chicago, 1998); Gayatri Chakravorty Spivak, "The Rani of Sirmur: An Essay in Reading the Archives," History and Theory 24, no. 3 (October 1985): 247-72; Ann Laura Stoler, Along the Archival Grain: Epistemic Anxieties and Colonial Common Sense (Princeton, 2010). See also Antoinette Burton's "Archive Stories: Gender in the Making of Imperial and Colonial Histories," in Levine, ed., Gender and Empire, 281-93.

92 Looking at the silence and secrecy in the archives is, of course, not an exclusive method of imperial histories. I also draw from social and intimate histories like the one recently offered in Deborah Cohen, Family Secrets: Shame and Privacy in Modern Britain (Oxford, 2013).
} 
transformations on imperial and global scales without necessarily assuming the centrality of Britain.

Tracing how global transformations have shaped lives at the level of the local and intimate could thus invite new historical actors hitherto neglected from histories of Britain and the world (and international history more broadly). It could, for example, explain how often unwaged women and young people participated in aid programs through fair trade and charity shopping, and how, in turn, these shops transformed labor relations (not always for the better) in postimperial economies like India. It is entirely possible to write a history of how everyday life in Britain became engaged with, or shaped by, the wider world while remaining critical of imperial amnesia or a default liberal internationalism. Looking at the history of economic lives is just one arena that can allow us to study local historical actors and connect them to postimperial and international transformations.

In response to the rising spirit of nativism and anti-internationalism around the world, the historian Jeremy Adelman has recently lamented how we have "put our stock in the magnetism of the market and the empathetic power of a cosmopolitan spirit that appeared to take hold of the upper echelons of a higher education committed to an idyll of global citizenship. ${ }^{\prime 93}$ But a global approach to the history of Britain could offer more than a celebration of liberal internationalism and its privileged subjects. Reading beyond the campaign brochures and governmental and nongovernmental policies, minutes, and proceedings can help us recover how Britons came to think of themselves as citizens of the world, how they constructed a mythos of liberal internationalism, and who was included and excluded from it. It can help us avoid reproducing the worldviews of liberal internationalists, and at the same time, can move us beyond a moralizing tone in weaving our narratives. Rather than policing its boundaries, it could offer a capacious understanding of the possibilities of writing histories of Britain and the world.

\section{AFTERWORD: BRITAIN AND THE WORLD}

\section{Catherine Hall}

How to think about "Britain and the world" was the topic of a lively session at the 2016 NACBS conference in Washington, DC, that inspired this collection of reflections. It was a strange and disturbed conference, opening as it did the day after Trump's election. Participants were in shock, trying to absorb the two political earthquakes of Brexit and Trump, both with serious implications for British historians, whether in the United Kingdom or the United States. Did the vote for Brexit mean that a cosmopolitan vision of the United Kingdom was doomed for the foreseeable future as Britons retreated into a right-wing nationalist and populist state of mind, celebrating an "island story" and refusing European connections, never mind those beyond? Did Trump's election mark a watershed for the future of university history teaching and funded historical research in the United States? In the autumn of 2016, Gramsci's insistence on pessimism of the intellect and optimism of the will seemed particularly appropriate. Think hard and hold on. ...

${ }^{93}$ Adelman, "What Is Global History Now?" 
Many months later, things look rather different as Trump is assailed on so many sides and the public mood in Britain has moved significantly away from a Tory hegemony. As historians, we are supposed to take the long view, but the current levels of political volatility and the sense of the tectonic shifts that underpin the changes make thinking about the future particularly difficult.

The naming of jobs and courses in British history as "Britain and the world," particularly in US institutions, obviously signifies something new. The four commentaries on what this "new field," if that is what it is, might mean-from Miles Ogborn, James Vernon, Priya Satia, and Tehila Sasson-provide much food for thought. Together they give us a set of questions. First of all, as Miles Ogborn puts it so beautifully, what does that and carry? That crucial little connector. ... Which Britain? Which world? Whose world? Which thinkable connections? When? Is that and an open-ended invitation to explore, imagine, and debate what the relation between those terms might be? Or is it, in part, the product of something more pragmatic - a response to the restructuring and downsizing of US history departments, as James Vernon suggests, and the need for British historians to turn their hands to something different? Once we have a sense of what it involves, what are the possibilities and pitfalls associated with this shift?

Priya Satia welcomes the possibilities opened up by an emphasis on Britain in relation to other places. Its critique of a narrow nationalist perspective has the potential for a more inclusive worldview. But she warns too of the dangers. Is this a "fix for provincialism or a case for colonialism," as she neatly puts it in her title? Might the new name encourage the delusion that Britain is still at the center of the world? Is there a danger of a loss of texture and of local specificity in the determination to be transnational? Satia reminds us that what is represented as new has often been seen before, but usually there is a new twist; history does not simply repeat itself, and for the most part, historians do not either. There were, of course, feminists who wrote women's history before the women's movement of the 1970s, and there were imperial historians who were thinking about the relation between metropole and colony before the "imperial turn." What was new were the political imperatives that compelled whole cohorts to address the pressing question of where were the women, or the amnesia that was such a striking aspect of Britain's relation to its empire and became so apparent in Britain's postcolonial moment. The work that was produced was on such a scale that eventually it transformed, albeit only to a certain extent, the mainstream. Is this likely to happen with "Britain and the world"? There have been academics teaching courses about "Britain and the wider world" for decades, but does the new naming of academic jobs mean that we going to see British history in its narrowly domestic definition now permanently declining as a subject in US institutions? There would be good reasons for this- most obviously, Britain's loss of power, which has made it less significant both for North Americans and geopolitically, a reality with consequences in terms of demand from students and the public.

It is perhaps worth saying that there will always be a place for domestic histories, whether of Britain, the United States, or all those new nations and "small islands" whose historians were so preoccupied with constructing new histories for themselves in the wake of decolonization and independence. All aspects of states and societies need to be placed in a global frame, but there is room for detailed local studies too. Domestic histories are not necessarily nationalist. One particularly influential 
version of British history, devoted to undoing the Whig paradigm of progress, was that of the Marxist historians who saw their prime task as the rewriting of English and British history through the paradigm of class and revolution. That group came together in the wake of the Second World War and the onset of the Cold War, all of which provided a backdrop to 1956. Then 1968 brought the "turn" to feminist and gender history. Challenging the ways in which particular versions of national and domestic history have been written is a necessary part of pluralizing national identities and undoing myths of homogeneity. My work on Thomas Babington Macaulay was in that spirit, attempting to undo his insular masculinist history of England by demonstrating the ways in which he erased the centrality of both gender and empire to his thinking and being. Our increased awareness of connection, entanglement, interdependence, and the inequalities of power on imperial and global scales should not mean that we close our eyes to the importance of domestic histories. The issues we face in the United Kingdom in the post-Brexit, post-election time make this abundantly clear. We need detailed analysis of changes that have their roots in the late 1970s - the effects of globalization, deindustrialization, the overreliance on the financial and service sectors, the shrinking of both the local and central state, the levels of privatization and corporatization, the new patterns of the zero-hours economy, and much more. There is much work here for historians as well as sociologists and others.

The new interest in the history of capitalism provoked by the financial crisis of 2007-2008 reminds us that its grand narrative, along with those of industrialization and colonialism/imperialism, has always been both local and global, a point that Priya Satia underlines. We only need to read the first volume of Marx's Capital to remember that, or turn to such classics as Eric Wolf's Europe and the People without History. The effects of these processes are of course very different in different locations, and the increased spatial awareness of contemporary historians is very welcome. Satia's work on the Galton family-deeply embedded in the metal industries of Birmingham and the Black Country, the national culture of the Quakers, and the complex networks of transatlantic trade with their systems of credit and exchange and their dependence on European merchants and African chiefs-provides a telling example of how gun making had such differently impacts on the peoples and the economic development and underdevelopment of the West Midlands and West Africa. At one node on this circuit was the Galton family with their particular expectations for their husbands and wives, sons and daughters, their workforce of skilled and unskilled male and female labor; at another were enslaved Africans in the dungeons of Cape Castle or en route to the Americas. How to do justice to these different histories, to capture these voices and grasp these varied structures, is a truly demanding task. What is clear is that the new histories of capitalism that do not pay attention to the global systems in which cotton or sugar or tea were located will not do. While the current work on US capitalism is most welcome, the racial characteristics of that system are not always placed center stage. ${ }^{94}$ While the grand narratives of the past have been rightly critiqued, this does not mean that we should abandon

\footnotetext{
${ }^{94}$ See Priya Satia's review of Sven Beckert in Journal of Modern History 88, no. 3 (September 2016): 640-42; and Peter James Hudson, "The Racist Dawn of Capitalism: New Books on the Economy of Bondage," Boston Review 42, no. 2 (March/April, 2016): 42-48.
} 
metanarratives that attempt to connect the micro with the macro. Rather than one grand theory, however, perhaps we need something more like a patchwork, a quilt that can gradually be put together, with its complex patterns and different axes of power.

Tehila Sasson, someone who came of age with the global turn, emphasizes that what matters about taking "Britain and the world" as the unit of analysis is the questions that are asked. Who are the subjects of a global history of Britain? And how might the relation between the local and the global be addressed? Is this discussion really about a method of inquiry, one that reads against the grain and is preoccupied with the voices of those whose lives were shaped by new international forces as well as with the voices of the agents? Her example of the new histories of humanitarianism points to the need to move beyond empire, to think about how British lives are lived in a global frame. A focus on empire alone makes for boundaries that are rarely sealed. Studying the eighteenth-century Caribbean, for example, on the islands of St. Lucia, St. Vincent, or Trinidad, means grasping the place of the French and Spanish empires in these histories, and the geopolitics with which the colonists were engaged, whether they wanted to be or not. Miles Ogborn's Global Lives was one of the first books to invite historians to think globally about the lives of both "ordinary people" and major historical figures. James Delbourgo's 2017 Collecting the World: The Life and Curiosity of Hans Sloane ${ }^{95}$ documents the subaltern histories that made possible the notion of "collecting the world." Sloane sits at the center of the web, but Delbourgo's narrative is also peopled with the unnamed enslaved men and women in Jamaica who collected for Sloane, the artists who drew for him, the myriad contacts in the trading companies who acted for him. This was the network of characters, together with his rich, slave-owning wife and his domestic servants-who made this so-called independent gentleman what he was.

It is daunting to take on the complexity of the world in both the past and the present and to grapple with the skills the historian needs if that complexity is to be truly addressed. The language training that is required for graduate students in history departments in the United States has never been a requirement in Britain and leaves many of us here with appalling gaps, only made worse by the shrinking of language teaching in British schools and universities, associated with a lamentable notion of the triumph of English as "the world language." The levels of work that are necessary if different localities, regions, and colonial/national cultures are to be adequately understood for any piece of historical investigation pose serious challenges. There are good reasons for the development of specialisms, and another concern is that historians seen as able to deal with Britain and the world might displace South Asianists or Africanists with their regional skills and knowledges. At a time when academics are expected to produce so quickly and consistently-demands that are profoundly out of key with the nature of historical scholarship-it will be tempting for some, rather than embarking on transnational or transcolonial or world history, to settle for a tighter focus on a boundaried place, a small piece of microhistory. The pressures on young historians with the ever-increasing number of contract positions, alongside the expectations around teaching and administrative

\footnotetext{
${ }^{5}$ Also published as Collecting the World: Hans Sloane and the Origins of the British Museum (Cambridge, MA, 2017).
} 
and pastoral skills, are heavy burdens. Given all this, one response must be to turn to more collaborative enterprises-encouraged institutionally in some respects but at odds with the individualistic and deeply competitive ways in which scholars in the humanities are judged.

In reflecting on the emergence of "Britain and the world," James Vernon focuses on the institutional context for this "new field," the shrinking job market in the United States, and difficult futures of $\mathrm{PhD}$ candidates. But he also sketches out the different political conjunctures which have produced new "turns" and shifts in historical writing over the past forty years. J. G. A. Pocock's plea from New Zealand in the 1970s for new understandings of British history came in the wake of decolonization and the questions as to how the "Commonwealth" and the "Atlantic archipelago" might figure in the context of Britain's new relation to the European Union. The development of nationalist movements in Scotland, Wales and "the Troubles" in Northern Ireland brought attention to the "four kingdoms" and an increasing awareness of the problem of calling England Britain, something that was also a focus for the "new imperial history" of the 1980 and '90s. And so to "world history" and "global history," the drivers for which were globalization and the geopolitical changes of the late twentieth century. All of this is to say that significant shifts in perspectives are driven by significant changes in the world and in politics and the responses that historians make to those changes. What are the "politics of location," to use the term first developed by feminists, in any particular time and place, what demands arise from this, what is the work that might cast light on contemporary processes in illuminating ways? Of course, not all historical writing is driven in these ways; there is always the market, and there will always be people with particular passions wanting to explore places and temporalities that may have no apparent connection to the present but may well have a relation to their own lives and their own psychic needs. Moreover, "the politics of location" can be associated with refusal and denial on the part of historians as well as the general public. There are imperatives that can block the pursuit of particular topics and encourage avoidance of subjects too painful or dangerous to explore. It was almost impossible, for example, for Germans to think about the Holocaust in its immediate aftermath, and Aboriginal histories have moved in and out of the concerns of white Australian historians over the period since colonialism. ${ }^{96}$

Perhaps in conclusion it might make sense to come back to the question of collaboration and see the need for this as a positive aspect of a worldly British history, one which, in Vernon's terms, is conscious of how worldly historical processes made Britain. A model of history writing that emphasized the collective rather than the individual enterprise, that put the focus not on individual achievement, this "great book," or that "amazing article" but rather on how such work is made: the talk, the exchange, the sharing of research and archival knowledge that is part and parcel of being an historian. If better understandings of Britain's relation to other parts of the world, whether the profound inequalities of empire, the shifting parameters of European power, or the many and varied relations to other places and peoples across time, are to be grasped, it needs a collective enterprise, one in which different

\footnotetext{
${ }^{96}$ For the significance of "denial" to historical work, see the special section "Feature: Denial in History," History Workshop Journal 84, no. 1 (Autumn 2017): 1-148.
} 
contributions can be made from a variety of different perspectives. Histories will always be contested, and historians will always argue and disagree-as they should. This is the stuff with which we work. I return to that notion of the quilt, laboriously pieced together by the labor of many: perhaps that image provides a relatively optimistic vision of a decentered and provincialized Britain, with a more modest understanding of its place in a wider world. 